\title{
Evaluation of an Organic Waste Composting Device to Household Treatment
}

\author{
Susana Boeykens ${ }^{* 1}$, C. Alejandro Falcó ${ }^{2}$, Maria Macarena Ruiz Vázquez ${ }^{3}$, María Del \\ Carmen Tortorelli ${ }^{4}$
}

${ }^{1}$ Heterogeneous Systems Chemistry Laboratory, Faculty of Engineering, University of Buenos Aires, P. Colon 850 BA, Buenos Aires, Argentina e-mail: sboeyke@gmail.com

${ }^{2}$ Heterogeneous Systems Chemistry Laboratory, Faculty of Engineering, University of Buenos Aires, P. Colon 850 BA Buenos Aires, Argentina e-mail: afalco@fundacion-enlaces.org

${ }^{3}$ Heterogeneous Systems Chemistry Laboratory, Faculty of Engineering, University of Buenos Aires, P. Colon 850 BA, Buenos Aires, Argentina e-mail: maca@gmail.com

${ }^{4}$ Ecotoxicology Research Program, Department of Basic Sciences, National University of Luján, Ruta 5 y Avenida Constitución, Buenos Aires, Argentina e-mail: mctortorelli@fibertel.com.ar

Cite as: Boeykens, S., Falco, C. A., Ruiz Vázquez, M. M., Tortorelli, M. D. C., Evaluation of an Organic Waste Composting Device to Household Treatment, J. sustain. dev. energy water environ. syst., 3(3), pp 245-255, 2015, DOI: http://dx.doi.org/10.13044/j.sdewes.2015.03.0019

\begin{abstract}
The performance of a plug-flow automated aerobic digester used with the compost of the Biodegradable Organic Waste (BOW) from a typical family at its generation rhythm was evaluated. During a 13 month assessment, $179.7 \mathrm{~kg}$ of BOW were treated and $106.7 \mathrm{~kg}$ of compost were obtained with a $\mathrm{C}: \mathrm{N}$ ratio of 12 and an average concentration of $\mathrm{N}$ of about $2.72 \%$. Additional tests enabled to assess the generation of stable and good quality compost according to the considered standards, suitable for using as organic fertilizer and other uses, such as biotreatments. The design, location and operational characteristics of the device have determined reduced leachate emissions, the absence of unpleasant odour generation and incidence of insects or other vectors, implying the viability of their use without affecting the user's life quality. It could be an efficient alternative treatment for household BOW, from a technical, economic, energy, cultural and environmental point of view, easy to implement for users lacking in special training.
\end{abstract}

\section{KEYWORDS}

Automated aerobic digesters, Household waste treatment, Composting, Plug-flow Biodigester.

\section{INTRODUCTION}

Municipal Solid Waste (MSW) treatment is one of the most visible environmental issues in urban areas of Argentina. This problem has been increasing as a result of urbanization and industrialization process, changes related with consumption habits of the growing population and their economic development. Urban communities in Argentina have found increasing difficulties associated with the MSW management due to political, regulatory, technical, institutional, financial problems, in addition with a reduced involvement of the citizens. In the Autonomous City of Buenos Aires, each person generates, in average, more than $1.23 \mathrm{~kg}$ of waste per day. In 2012 the total waste generation reported by the Ecological Coordination of the Metropolitan Area, Society of

\footnotetext{
* Corresponding author
} 
the State (CEAMSE), which was disposed without previous separation treatments in the Final Disposal Centres, was 6.5 million tons $(6,484,229$ tons).

At the other end of MSW management, we can choose cases such as Copenhagen, Denmark, where each person generates about $1.3 \mathrm{~kg}$ per day, but only $3 \%$ of this waste generation is finally disposed in landfills [1]. In Veracruz, México, segregation at source has led to a massive and positive participation of citizens, reaching a recycling rate of $56 \%$ of MSW generated, with an incineration of 39\% of MSW segregated, which has been used to produce electricity [2].

Among the various strategies that have been carried out in Denmark to successfully support the MSW management, some cities have offered compost devices free of charge to homeowners to compost their own organic food waste, consuming the entire compost generated in the family's garden [3]. This has greatly reduced the amount of waste that must be transported, separated, treated and disposed, with a significant impact on costs for the city. Besides, the food fraction segregation at source significantly has increased the recyclability of other waste streams, decreasing and eliminating costs of washing.

Household composting should not be seen as an alternative treatment option for all organic waste in a region, but as a complementary solution. It provides a flexible and low-cost solution to cooperate with waste management and facilitate sustainable recycling. Nevertheless, it requires the active participation of a significant proportion of citizens in order to have an impact on waste diversion rate. In comparison with community composting, the economic and environmental benefits associated with household composting, involve reduction of costs and impacts of the temporary disposal on the streets, reducing the expense of collection and transportation of organic waste, and leachate emissions in compactor collection trucks and transfer stations. Additionally, odours on the streets are reduced, also improving the epidemiological vectors control such as flies, rats, etc. Another significant advantage of composting both centralized and at home, is that the compost generated can be used as soil conditioner and amendment, replacing the use of synthetic chemicals. It improves the physical properties of the soil, increasing its water retention and essential nutrients contents [4-7].

There are a variety of implementation strategies for the composting process. Each family in each region has its own food culture, so a large dispersion in the characteristics of raw food waste can be generated, as well as in those of the compost obtained. Also, there could be different destinations for the compost that would determine their respective conditioning. It makes a complex system of multiple variables, which undoubtedly requires further and deeper studies in accordance with its potential direct impact on our own life quality $[3,8]$.

One of the obstacles in achieving a high percentage of residents involved in the implementation process of compost at home is the idea that the operation is "dirty" and it require a lot of personal intervention, added to prejudices about the inexorable existence of odors and flies, and the associated cultural refusal to make contact with "the garbage". An applicable strategy to accomplish active participation of a significant proportion of citizens is to offer low-cost small size devices, sufficiently automatic and easy to use, with features comparable to those of a simple-use appliance.

The objective of this research was to evaluate the efficiency of a device designed and built to operate automatically at home for household composting. The real scale biodigester is in its third year of receiving uninterruptedly, at the rhythm of the generation, all the food waste from a typical middle class family. The design of this new device was focused on the solution to the problems found with other types of bioreactors [7-10]. These authors suggest procedures that involve discontinue the charge during a period of three months to achieve the compost maturation before sampling for analysis. 
Consequently, the process was associated with a change of the ideal operating conditions provided by the need of dispose the wastes as they are generated. In this work, a plug-flow operation is proposed: the waste enters through a receiving chamber, and it is removed from the last maturation chamber, at the other end of the device.

\section{METHODOLOGY}

\section{Materials used for composting}

The qualitative composition of the BOW corresponds to residues of animal and vegetable products generated during the preparation of family meals, from dishes and kitchen utensils cleaning, and other organic residues (such as paper napkins, etc.). Green wastes from garden pruning were also included when the digester received abundant meat scraps.

The study period was extended by thirteen months (February 1, 2011 until March 1, 2012), totalling 394 days. During this time, the digester received a total amount of 179.7 $\mathrm{kg}$ of ROB, which equates to an average of $446 \mathrm{~g} / \mathrm{day}$. In the case of the family considered, this volume was associated with the generation of $112 \mathrm{~g}$ per day per person of BOW, which implies a low rate of waste generation in comparison to average of this indicator. Adequate samples were taken for analysis from removed compost.

At the start of the study, the net weight of organic matter and biota existing within the digester was $57.00 \mathrm{~kg}$, coincident with the weight on the end date of the evaluation to simplify the accumulation variable in the overall mass balance.

\section{Biodigester description}

The composting operation was performed with a plug flow aerobic digester device without forced aeration [11]. The device has a cylindrical geometry, with a total internal volume of $0.14 \mathrm{~m}^{3}$ divided into three chambers (Figure 1). It was built of stainless steel with polyurethane insulation. It has an automatic rotation and programmable system (rotation speed range: $0.5-10 \mathrm{rpm}$ ), allowing the rotation frequency adjustment with a sensitivity of $\mathrm{min} /$ week.

Slow and pulsating flow between the chambers is regulated by a control system, included in the biodigestor mechanism. The controlled variables are speed, frequency and duration of rotation, aperture of the gates dividing plates between cameras, and horizontal inclination angle of the whole.

The fresh BOW is collected at the same rate of its generation in a bucket of $1.5 \mathrm{~L}$. Every time the bucket's content is completed, it is loaded into the digester. The loading is performed through a gate located in the first chamber, which operates with compost in an initial state of mesophilic degradation. In the intermediate chamber, thermally insulated, waste progress to aerobic decomposition stage, associated with the mesophilic phase completion and the thermophilic stage beginning [12]. When the process is finished, the stabilized compost is removed from the gate located in the third chamber, where it is also possible to extract samples for analysis. The opening degree of the slit over the dividing plates controls the waste residence time in each chamber. During the experimentations, it was possible to close one chamber during the time for an evolution study, whereas the other chambers were still operating.

The design includes a filter system located at the bottom of the last chamber, allowing any leaching drip collection on a lower tray.

The absence of forced aeration was foreseen in the design to minimize the energy consumption and to improve the operational autonomy. Aerobic conditions are insured by the device high frequency rotation. Other authors discusses the different types of 
devices for aerobic household composting that operate at maximum mixing frequencies of 1 rotation/week [9]. For this study, the designed device was scheduled to generate a daily rotation during $1 \mathrm{~min}$, at $3 \mathrm{rpm}$, equivalent to three rotations per day, resulting in a significant mixing of the content. Power consumption is reduced to the rotation, which is performed by an asynchronous three-phase motor of $0.09 \mathrm{~kW}$ nominal power, scheduled to work only 1 min per day for this test. Due to the equipment internal design, waste is crushed during the rotation, using the same energy for mixing and aeration. The device does not consume water or fuel. Due to the low power consumption required, the device could even work autonomously powered by a small solar panel.

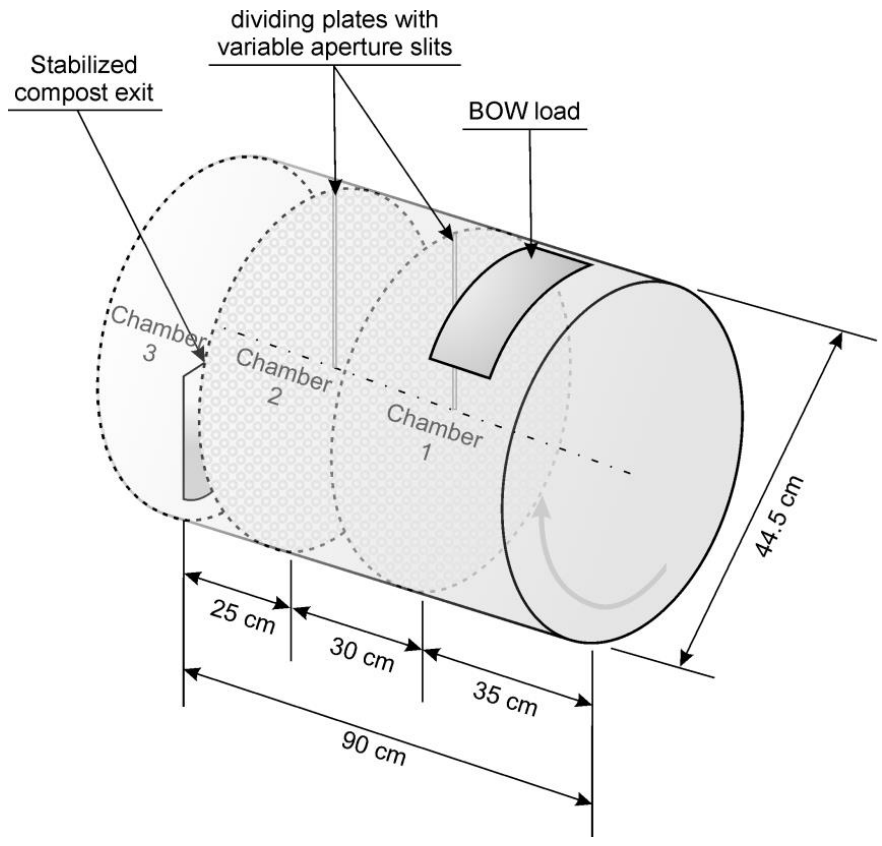

Figure 1. Schematic drawing of the digester with dimensions

\section{Monitoring and analysis}

The whole device is mounted on two cells of a Balcoppan Challenger SC103 balance, connected via RS 232 to a computer. Through a specially developed software, the weight is recorded every $15 \mathrm{~min}$ automatically. In this way, it is possible to make a correct monitoring of the amount and time when fresh BOW is loaded or stabilized compost is removed, and weight variations experienced by the material mainly because of water exchange with the environment. All the operations are recorded, with a comment, if necessary. The weight of the device body is $23.5 \mathrm{~kg}$ (Tare).

As a consequence of the digester content homogeneity, the monitoring sampling was carried out by direct removal. Thus, one sample of each of the chambers was arranged on a plastic cover on the ground, expanded on the surface and divided into four parts, through four proportional diagonal cuts. Of these, two quarters were chosen randomly.

Humidity, temperature, conductivity and $\mathrm{pH}$ were weekly studied. The absolute humidity was analysed using a Fischer heater and a DLT-211 Denver Instrument electronic balance [13]. The $\mathrm{pH}$ was measured with a $\mathrm{pH}-222$ Lutron portable digital pHmeter and the conductivity was measured with a portable digital conductivity meter Altronix Model CT-2 [14]. The temperature was measured by a manual dial thermometer incorporated into the digester, and a digital portable thermometer was introduced into the compost for a quick reading. Analysis of additional parameters, such as Respirometric Index (RI), Total Organic Carbon (TOC), N, P, Ca, Mg, Na, K, Fe, Zn and Mn 
concentrations, germination and Root Elongation (RE) tests, and Particle Size Distribution (PSD) were also carried out [14].

For monitoring the presence of insects, special traps were used (Bell Laboratories, Inc.) to determine the type and amount of insects and small mammals circling the digester. They are resistant cardboard traps (approximately $178 \mathrm{~mm} \times 89 \mathrm{~mm}$ ) with an adhesive portion that holds them to the digester, placed at $3 \mathrm{~cm}$ from the gate to BOW entry. Each trap has a highly adhesive surface exposed to the environment where organisms are retained. Four measuring campaigns of insects and small mammals were carried out during the study, using for each opportunity three traps in the digester, with an exposure of five days.

\section{RESULTS AND DISCUSSION}

The overall mass balance is:

$$
I=O+D b R+A
$$

Where $I$ (input) is the mass of BOW load, $O$ (output) is the mass of stabilized compost removed, the term $D b R$ (Disappearance by Reaction) is weight loss that involves the reaction of aerobic composting where organic carbon is gasified to become $\mathrm{CO}_{2}$, and the term $A$ (accumulation) represents the accumulated mass inside the reactor.

Table 1 summarizes, as example, monthly mass balances during one year of the study. Column 1 represents the sum of the BOW loaded during that month, column 2 the amount of compost removed, column 3 is the difference between the reading of the display of the balance the first day of this month, and the first reading of the following.

Table 1. Monthly and total mass balances

\begin{tabular}{cccc}
\hline Month & $I[\mathrm{~kg}]$ & $O[\mathrm{~kg}]$ & $A[\mathrm{~kg}]$ \\
\hline Feb-11 & 16.8 & 1.2 & 0.00 \\
Mar-11 & 12.24 & 1.1 & 9.75 \\
Apr-11 & 11.6 & 10.7 & -4.45 \\
May-11 & 16.6 & 1.7 & 7.20 \\
Jun-11 & 12.1 & 10.2 & 0.15 \\
Jul-11 & 10.4 & 5.3 & 1.30 \\
Aug-11 & 14.0 & 19.4 & -7.75 \\
Sep-11 & 17.0 & 18.5 & -6.25 \\
Oct-11 & 12.4 & 11.6 & -3.25 \\
Nov-11 & 19.3 & 17.3 & -4.95 \\
Dec-11 & 11.0 & 1.4 & 3.45 \\
Jan-12 & 11.5 & 7.1 & -3.00 \\
Feb-12 & 14.7 & 1.3 & 7.80 \\
\hline Average & 13.8 & 8.2 & 0.00 \\
\hline Total & 179.69 & 106.7 & 0.00 \\
\hline
\end{tabular}

As a result of the process, there was a weight reduction rate of $40 \%$ (wet basis) between the BOW that entered the device and the mature compost generated. Throughout the study, annual average weight reduction values were similar to those indicated. Some previous works examine and compare different composting methods mentioning weight reduction rates (wet basis) in a range of 50-70\%, considering this parameter as indicator of the compost stabilization. These values depend on the type of device, BOW, inoculums, and the 
biotic mixture developed in each digester in their particular conditions. Once the compost stabilization is demonstrated as a result of additional tests, the lower weight reduction means a greater retention of carbon, nitrogen and other nutrients, resulting in better properties for soil amendment $[3,8,15]$. Based on the life cycle analysis of waste treated by household composting, obtaining a stable compost that satisfies the recommended values with the fewest loss of Organic Matter (OM) possible, implies the reduction of the waste carbon footprint, and its impact on climate change.

The residue average residence time on this device was 137 days, which represents the total duration of the BOW composting process for this plug flow system. Figure 2 show the results of a typical weight evolution in two weeks during the study. The general trend in weight reduction inside the device calculated was $0.25 \%$ per day. Recorded daily oscillations are due to the exchange of water with the environment, the liquid-vapor equilibrium displacement causes alternatively weight gains and losses of around $2 \%$ per day, which means values greater than $1 \mathrm{~kg}$ of water were gained and lost throughout the day.

The C:N ratio (total organic carbon/total nitrogen) is used as a compost quality and nitrogen availability indicator $[3,16]$. In Argentina, its limit was established in less than 20 for organic amendments, according to the Spanish and Australian regulations. American and Chilean standards, agree with the requirement of a $\mathrm{C}: \mathrm{N}$ ratio lesser than or equal to 25 for class A compost, and lesser than 30 for class B compost. The rules mentioned above require further analysis to classify into two possible groups. In Group 1,

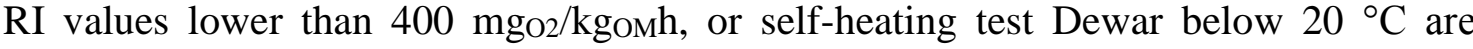
required. In Group 2, RE values above 0.8 are demanded [17-21]. In the case of stabilized compost extracted from the digester under study, the results summarized in Table 2 indicate values to consider that the compost extracted is very mature, it has reached acceptable stabilization to class A, and for both Group 1 or 2 .

$\mathrm{RE}$ values $\geq 0.8$ indicates no phytotoxic substances presence or very low concentration. A value $\leq 0.5$ may indicate a strong presence of phytotoxic substances and values between 0.5 and 0.8 could be interpreted as moderate presence of these substances. By contrast, if the samples values exceed 1.2, it is considered that the tested product is a growth promoter $[20,25,26]$. Results show evidence of root growth promotion in both species using the compost generated by the device in study.

The results of humidity determinations indicate that they exceed the reference values. The limits considered for moisture in the compost are related to the reduced aeration capacity of the considered systems, and the consequent risks of anaerobiosis and odor generation [20]. In different published works, higher values in the range of 50 to $75 \%$ of humidity were found $[3,8,24]$. The ideal humidity content for composting depends on the water retention capacity of the material being composted. In general, high content of OM confers hygroscopicity to the mixture. For the device under study, the daily rotation involves a mechanical contribution to oxygenation allowing higher humidity values and improving the rate of decomposition.

Conductivity is related to the concentration of total soluble, dissolved or suspended salts in the medium. High levels of salinity can be toxic to some sensitive plants. The acceptable level of soluble salts depends on the proposed use of the compost. Results presented here are low enough to very mature compost.

Standards require maximum average compost PSD of $16 \mathrm{~mm}$. Figure 3 shows the particle size distribution of the compost tested, showing compliance with this requirement.

All the campaigns for monitoring presence of insects and small mammals have showed negative results, revealing absence of insects in the digester area. This was 
confirmed with daily visual observations, accounting absence of insects and unpleasant odor generation.

The volume of leachate generated was approximately $1.1 \mathrm{~cm}^{3} / \mathrm{kg}$ per day (wet basis). This may explain the high levels of humidity founded in the compost in this work. Other works reported values from zero to $40 \mathrm{~cm}^{3} / \mathrm{kg}$ per day (wet basis) $[3,10,27,28]$. The leachate generation is a potential cause of nitrogen loss in stabilized compost and represents environmental impact associated with potential eutrophication as a result of its emission to natural water bodies. Several studies have reported significant loss of nutrients (especially nitrogen) in leachate resulting from composting experiences [8, 29, 30]. It should be noted the high average value of nitrogen registered, significantly higher than the minimum required by the standards. The nitrogen content is reduced during composting, but it is desirable to retain as much as possible [31]. The high value of RE reached evidence the fertilizer capacity of the compost obtained, determining that their use as organic amendment supports crop growth.

Taking into account the characteristics of the compost obtained it is convenient to be used as soil amendment. As a result of the process, $106.7 \mathrm{~kg}$ of good quality compost were removed and arranged in the garden and plant pots.

Table 2. Average and reference values of physicochemical and biological variables measured on mature compost removed from the third chamber of the device under study

\begin{tabular}{|c|c|c|c|}
\hline & $\begin{array}{l}\text { Average } \\
\text { value }\end{array}$ & Analytical method & $\begin{array}{l}\text { Reference } \\
\text { values }\end{array}$ \\
\hline Humidity [\%] & 56.4 & SM 2540B & $\begin{array}{c}\text { between } 30 \text { to } 45^{21,22} \\
50 \text { to } 70^{24}\end{array}$ \\
\hline Density $\left[\mathrm{kg} / \mathrm{m}^{3}\right]$ & 652 & TMECC 3.01-A & $<700^{21}$ \\
\hline $\mathrm{pH}$ & 7.2 & TMECC 4.11-A & 5.0 to $8.5^{20,21,22}$ \\
\hline TOC $[\%]$ & 33.9 & TMECC 4.02-D & $>20^{21}$ \\
\hline Total N [\%] & 2.72 & TMECC 4.02-D & $\begin{array}{c}>0.5^{21} \\
<6^{23}\end{array}$ \\
\hline Conductivity [dS/m] & 3.2 & TMECC 4.10-A & $\begin{aligned} &<3 \text { Class } \mathrm{A},<8 \text { Class } \mathrm{B}^{21} \\
&<4^{17}\end{aligned}$ \\
\hline $\mathrm{C} / \mathrm{N}$ & 12 & - & $\begin{array}{c}<25 \text { Class A, } \\
<30 \text { Class } \mathrm{B}^{21,22} \\
<20^{17}\end{array}$ \\
\hline $\mathrm{P}[\%]$ & 0.32 & TMECC 4.03-A & -- \\
\hline $\mathrm{RI}\left[\mathrm{mg}_{\mathrm{O} 2} / \mathrm{Kg}_{\mathrm{OM}} \mathrm{h}\right]$ & 350 & TMECC 5.08-B & $\begin{array}{l}<400 \text { mg class } A^{21,22} \\
<500 \text { very mature }\end{array}$ \\
\hline RE Lactuca sativa & 1.34 & TMECC 5.05-A & $\begin{array}{l}<0.8 \text { inhibition } \\
>1.2 \text { exaltation }^{20}\end{array}$ \\
\hline RE Raphanus sativum & 1.45 & TMECC 5.05-A & $\begin{array}{l}<0.8 \text { inhibition } \\
>1.2 \text { exaltation }^{20}\end{array}$ \\
\hline Dewar Self-heating test $\left[{ }^{\circ} \mathrm{C}\right]$ & 1.8 & TMECC 5.08-D & $\begin{array}{c}<20^{\circ} \mathrm{C}^{20,21} \\
<8^{\circ} \mathrm{C}^{22}\end{array}$ \\
\hline $\mathrm{Ca}[\mathrm{mg} / \mathrm{kg}]$ & 54 & TMECC 4.05-Ca & -- \\
\hline $\mathrm{Mg}[\mathrm{mg} / \mathrm{kg}]$ & 16 & TMECC 4.05-Mg & -- \\
\hline $\mathrm{Na}[\mathrm{mg} / \mathrm{kg}]$ & 72 & TMECC $4.05-\mathrm{Na}$ & -- \\
\hline $\mathrm{K}[\mathrm{mg} / \mathrm{kg}]$ & 229 & TMECC 4.04-A & -- \\
\hline $\mathrm{Fe}[\mathrm{mg} / \mathrm{kg}]$ & 1,352 & TMECC 4.05-Fe & -- \\
\hline $\mathrm{Zn}[\mathrm{mg} / \mathrm{kg}]$ & 212 & TMECC $4.06-\mathrm{Zn}$ & $1100 \mathrm{ppm}^{23}$ \\
\hline $\mathrm{Mn}[\mathrm{mg} / \mathrm{kg} \mathrm{SM}]$ & 337 & TMECC 4.05-Mn & -- \\
\hline
\end{tabular}



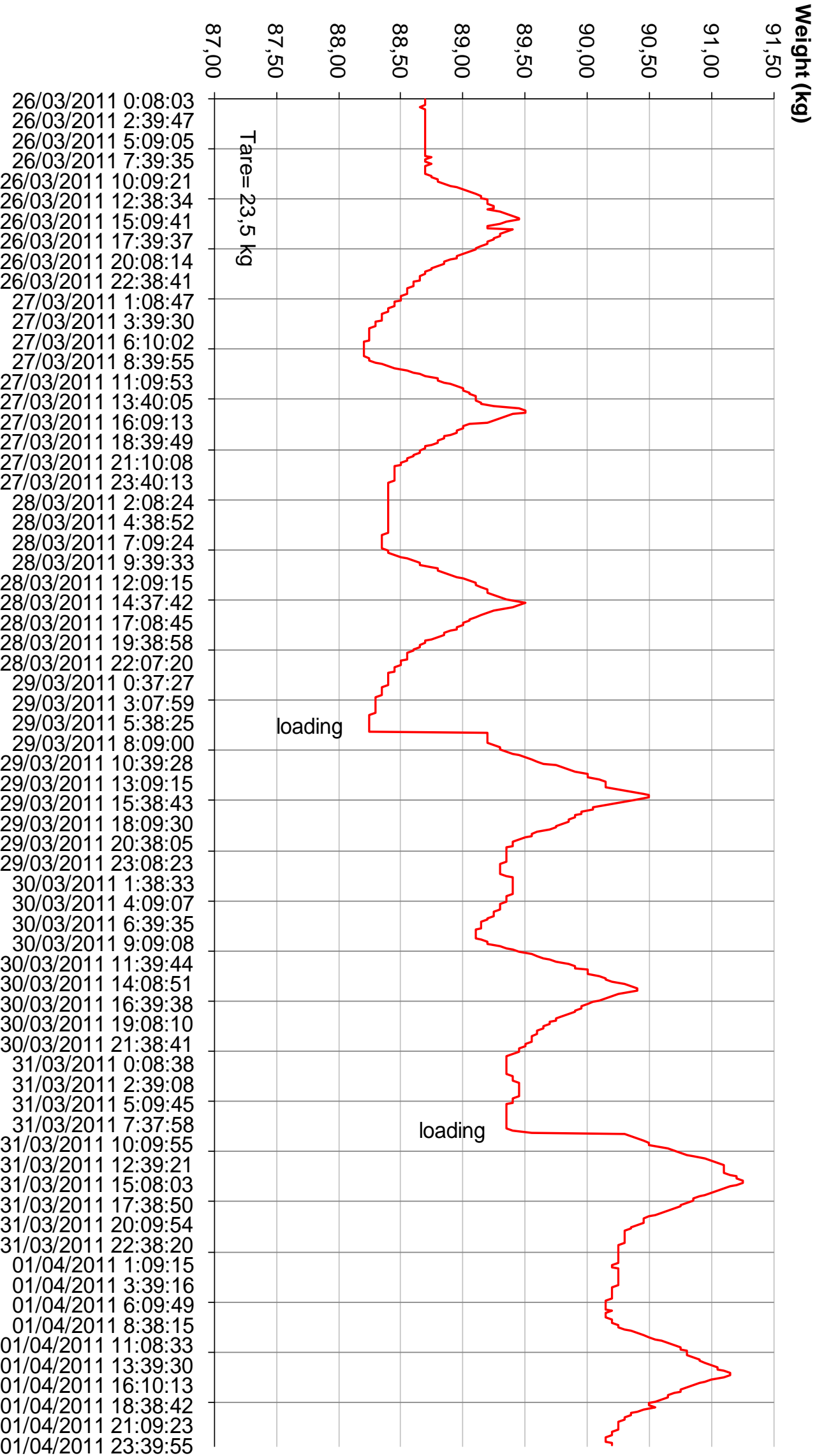

26/03/2011 15:09:41

26/03/2011 17:39:37

26/03/2011 20:08:14

26/03/201122:38:41

27/03/2011 1:08:47

27/03/20113:39:30

27/03/20116:10:02

(7)

27/03/2011 13:40:05

27/03/2011 16:09:13

(2)

27/03/2011 21:10:08

28/03/2011 9:39:33

28/03/2011 12:09:15

(28):

28/03/2011 17:08:45

29/03/2011 0:37:27

29/03/20113:07:59

$29 / 03 / 20115: 38 \cdot 25$

30/03/2011 9:09:08

30/03/2011 11:39:44

30/03/2011 14:08:51

$30 / 03 / 201121: 38: 4$

11/03/2011 0:08:38

31/03/2011 5:09:45 $31 / 03 / 20117: 37: 58$

31/03/2011 10:09:5

$31 / 03 / 201117 \cdot 38: 50$

(20.09:54

01/04/2011 21:09:23

01/04/2011 23:39:55

Figure 2. Weight evolution during a typical week 


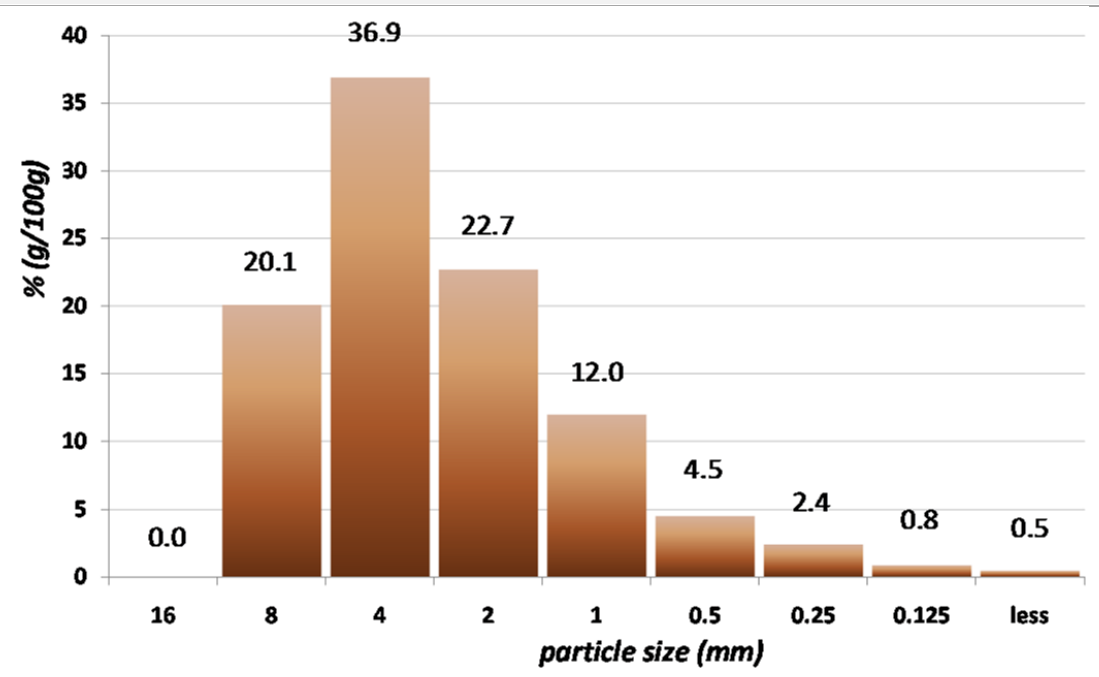

Figure 3. Particle size average distribution of stabilized compost removed from the third chamber of the device under consideration

\section{CONCLUSIONS}

According to the reported results, it can be concluded that the compost resulting from BOW treatment on the device studied is a good quality material according to the rules considered, concluding that the tested device has performed a BOW efficient treatment.

The evidence of absence of odor generation and occurrence of insects and small mammals show the viability of installation and operation without impairing the user's quality of life. Furthermore, device characteristics allow simple and automatic operation, only requiring simple ROB loading and stabilized compost monthly collecting, in both cases through easy gate openings.

Consequently, the results of this study support the conclusion that household composting using the designed device is a simple and suitable alternative treatment for organic waste, from a technical, economic, energy, cultural and environmental point of view, which can be easily implemented by a non-specific trained user, significantly reducing the environmental impact of its own waste.

\section{ACKNOWLEDGEMENTS}

This research was supported by the Ministry of Science, Technology and Innovation (Argentina), within the Project: PICT38183/2005, the Buenos Aires University, within the Projects UBACyT I-750/2006, 20020090100102/2010, 20020120100201/2013, and, the NGO: Linkages for Sustainable Development.

\section{REFERENCES}

1. Petersen, C., Kielland, M., Statistik for hjemmekompostering 2001 (Statistics for home-composting, in Danish), Miljøprojekt $\mathrm{N}^{\circ} 855$, Miljøstyrelsen, Miljøministeriet, http://www2.mst.dk/udgiv/publikationer/2003/87-7972-960-6/pdf/87-7972-961-4.pdf, [Accessed: 25-August-2013]

2. Barradas Rebolledo, A., Gestión Integral de Residuos Sólidos Municipales, Estado del Arte, Instituto Tecnológico de Minatitlán, Veracruz, México, 2009.

3. Andersen, J. K., Boldrin, A., Christensen, T. H., Scheutz, C., Mass Balances and Life-cycle Inventory for a Garden Waste Windrow Composting Plant (Aarhus, Denmark), Waste Manag. Res. Vol. 31, pp 1934-1942, 2011, http://dx.doi.org/10.1016/j.wasman.2011.05.004 
4. McConnell, D. B., Shiralipour, A., Smith, W. H., Agricultural Impact-compost Application improves Soil Properties, Biocycle, Vol. 34, pp 61-63, 1993.

5. Jakobsen, S. T., Aerobic Decomposition of Organic Wastes II: Value of Compost as a Fertilizer, Resour. Conserv. Recycl., Vol. 13, pp 57-71, 1995, http://dx.doi.org/10.1016/0921-3449(94)00015-W

6. Hargreaves, J. C., Adl, M. S., Warman, P. R., A Review of the use of Composted Municipal Solid Waste in Agriculture, Agric. Ecosyst. Environ., Vol. 123, pp 1-14, 2008, http://dx.doi.org/10.1016/j.agee.2007.07.004

7. Martínez-Blanco, J., Muñoz, P., Antón, A., Rieradevall, J., Life Cycle assessment of the use of Compost from Municipal Organic Waste for Fertilization of Tomato Crops, Resour. Conserv. Recycl., Vol. 53, pp 340-51, 2009, http://dx.doi.org/10.1016/j.resconrec.2009.02.003

8. Colón, J., Martínez-Blanco, J., Gabarell, X., Artola, A., Sánchez, A., Rieradevall, J., Font, X., Environmental assessment of Home composting, Resour. Conserv. Recycl., Vol. 54, pp 893-904, 2010, http://dx.doi.org/10.1016/j.resconrec.2010.01.008

9. Andersen, J. K., Boldrin, A., Christensen, T. H., Scheutz, C., Greenhouse Gas Emissions from Home composting of Organic Household Waste, Waste Manag., Vol. 30, pp 2475-2482, 2010, http://dx.doi.org/10.1016/j.wasman.2010.07.004

10. Amlinger, F., Peyr, S., Cuhls, C., Greenhouse Gas Emissions from composting and Mechanical Biological treatment, Waste Manag. Res., Vol. 26, pp 47-60, 2008, http://dx.doi.org/10.1177/0734242X07088432

11. Tchobanoglous, A., Theisen, L., Vigil, S., Integrated Solid Waste Management, McGraw-Hill, 1998.

12. Mason, I. G., Mathematical modelling of the Composting Process: A Review, Waste Manag., Vol. 26, pp 3-21, 2006, http://dx.doi.org/10.1016/j.wasman.2005.01.021

13. APHA-AWWA-WEF, Standard Methods for the Examination of Water and Wastewater, 22nd Edition, 2012.

14.TMECC, Test Methods for the Examination of Composting and Compost, US Composting Council, Bethesda, MD., U.S.A, 2002.

15.Papadopoulos, A. E., Stylianou, M. A., Michalopoulos, C. P., Moustakas, K. G., Hapeshis, K. M., Vogiatzidaki, E. E. I., Loizidou, M. D., Performance of a New Household Composter during In-home testing, Waste Manag., Vol. 29, pp 204-213, 2009, http://dx.doi.org/10.1016/j.wasman.2008.03.016

16. Boldrin, A., Körner, I., Krogmann, U., Christensen, T. H., Composting: Mass Balances and Product Quality, In: Christensen, T. H. (Ed.), Solid Waste Technology and Management, John Wiley \& Sons Ltd., Chicester, 2010, http://dx.doi.org/10.1002/9780470666883.ch36

17. Servicio Nacional de Sanidad y Calidad Agroalimentaria (SENASA) Resol, No 264 12011, Reglamento para el registro de fertilizantes, enmiendas, sustratos, acondicionadores, protectores y materias primas en la República Argentina, Ministerio de Agricultura Ganadería y Pezca, Argentina, 2011.

18. Real Decreto 824/2005, Requerimientos Mínimos de la Calidad de un Compost, Boletín Oficial del Estado, №171, pp 25592-25669, España, 2005.

19. Australian Standard AS4454, Compost, soil, conditioners and mulches, Standards Australia, $4^{\circ}$ Ed., Sydney, NSW, 2012.

20. California Compost Quality Council (CCQC), Compost Maturity Index, Technical Report, 2001.

21. Instituto Nacional de Normalización (INN), Compost-Clasificación y Requisitos, Norma Chilena de Compost, № 2880/2004 (NCh 2880-2004), Chile, 2004.

22. Canadian Council of Ministers of the Environment (CCME), Guidelines for Compost Quality, Canada, 2005. 
23. Council of the European Communities (CEC), Council Directive 1999/31/EC, On the landfill of waste, Official Journal of the European Communities, N L 182/1-19, 1999.

24. Gray, K. R., Sherman, K., Review of composting, Part 1, Process Biochemistry, Vol. 6, No. 6, pp 32-36, 1971.

25.Zucconi, F., Pera, A., Forte, M., De Bertoli, M., Evaluating Toxicity in Immature Compost, Biocycle, Vol. 22, pp 54-57, 1981.

26. Varnero, M. T., Orellana, R., Rojas, C., Santibáñez, C., Evaluación de especies sensibles a metabolitos fitotóxicos mediante bioensayos de germinación, Tomo III, pp 363-369, in: El Medioambiente en Iberoamérica: Visión desde la Física y la Química en los albores del Siglo XXI, Editor: Juan F. Gallardo Lancho, Sociedad Iberoamericana de Física y Química Ambiental, Badajoz, Spain, 2006.

27. Ming, L., Xuya, P., Youcai, Z., Wenchuan, D., Huashuai, C., Guotao, L., Microbial Inoculum with Leachate Recirculated Cultivation for the Enhancement of MSWcomposting, J. Hazard. Mater. , Vol. 153, pp 885-91, 2008, http://dx.doi.org/10.1016/j.jhazmat.2007.09.040

28. Wheeler, P. A., Parfitt, J., Life Cycle assessment of Home composting, Proceedings of Waste 2002 Conference, Stratford, UK, 2002.

29.Parkinson, R., Gibbs, P., Burchett, S., Misselbrook, T., Effect of turning Regime and Seasonal Weather Conditions on Nitrogen and Phosphorus losses during Aerobic Composting of Cattle Manure, Bioresour. Technol., Vol. 91, pp 171-8, 2004, http://dx.doi.org/10.1016/S0960-8524(03)00174-3

30. Sommer, S. G., Effect of composting on Nutrient loss and Nitrogen availability of Cattle Deep Litter. Eur. J. Agron., Vol. 14, pp 123-33, 2001, http://dx.doi.org/10.1016/S1161-0301(00)00087-3

31. Giró, F., El compost como producto, Exigencias en la recogida, estándares y condiciones de aplicación, Jornada Internacional sobre la Gestión Integrada de Recursos y Residuos en la Unión Europea, Santander, Spain, 2002. 